\title{
The Women of Njal's Saga: An Ethics of Ambiguity?
}

\author{
Jørgen Veisland \\ Scandinavian Institute, University of Gdansk, Poland
}

Copyright $\mathrm{C} 2018$ by authors, all rights reserved. Authors agree that this article remains permanently open access under the terms of the Creative Commons Attribution License 4.0 International License

\begin{abstract}
The article applies Simone de Beauvoir's reflections on authentic being in her work The Ethics of Ambiguity (1947) and Julia Kristeva's concept of marginal womanhood as developed in Powers of Horror (1982) to central women characters in Njal's Saga and to the character of Njal himself. The woman Hallgerd, wife of Gunnar, asserts her power and independence by refusing to give Gunnar two locks of her hair to make bowstrings out of. The gift denied brings about the death of Gunnar. Hallgerd's refusal constitutes the culmination of a dialectic preconditioned upon de Beauvoir's concept of authentic being as a lack of being precipitating a continuous revolt and an on-going creativity, the subjective creation of being in opposition to an objective, imposed condition. The women of the saga, Hallgerd, Bergthora (wife of Njal), and Queen Gunnhild, possess a fury described by Kristeva as a marginal otherness that cannot be sublimated. Fury propels freedom and independence. The struggle for freedom is continuous as it is predicated upon the insight that the genuinely ethical task of women and men consists in seeking freedom while realizing the ambiguity of their situation: the freedom of the subject is created in opposition to an oppressive objective condition. The women of the saga engage in actions whose violence is designed to be an overt parody on the actions perpetrated by the men in the family feud. Some of the men are also aware of this ambiguity and manifestly display an ironic and self-ironic attitude to fate, i.e. the objective condition, understanding that it is a construction and a projection from within and that it is within their power to change it. This becomes apparent in Njal whose gender is indeterminate as he combines feminine and masculine features and as he accepts his death (by burning) not as the outcome of an incontrovertible fate but as a free choice.
\end{abstract}

Keywords The Icelandic Saga, Women, Ambiguity, Gender Equality, Fate, Irony

\section{Freedom and Ambiguity}

The women Hallgerd and Bergthora, wives of Gunnar of
Hlidarendi and Njal respectively, propel the action of Njal's Saga at least through chapter 77 which ends with the death of Gunnar. Contributing to his death, perhaps even causing it directly is Hallgerd's refusal to give him two locks of her hair to make a bowstring. The dialogue between wife and husband epitomizes the drama that pits free will against an objective condition, the central motif of the saga as I see it:

He spoke to Hallgerd: 'Give me two locks of your hair, and you and my mother twist them into a bowstring for me.'

'Does anything depend on it?' she said.

'My life depends on it,' he said, 'for they'll never be able to get me if I can use my bow.'

'Then I'll recall,' she said, 'the slap you gave me, and I don't care whether you hold out for a long or a short time.'

'Everyone has some mark of distinction,' said Gunnar, 'and I won't ask you again.' [1, p.128]

Hallgerd is slapped in the face by three successive husbands, Thorvald, Glum and finally Gunnar. The slap in the face she receives from Gunnar is especially distressing to her since she married him of her own free will and since he is an outstanding member of the community on Iceland, widely respected for his strength of character and leadership abilities. His statement in the exchange with Hallgerd makes it clear that he might have survived had he been able to continue shooting arrows at the attackers lead by Flosi. The two locks of hair become emblematic of feminine power that may indeed defeat an enemy when applied by the two sexes to the common good, and, if not applied will cause the death of one or both parties. The two locks of hair, symbolizing womanhood, are a gift withheld, and the denial precipitates dialectic of negativity whose immanent presence in the saga is finally manifested at this pivotal point in the drama, Gunnar's death. The negativity ensuing from the drama of gender opposition in the saga emerges at this advanced point, the end of chapter 77 , as freedom, here the freedom of a woman asserting herself as a subject revolting against an objective condition, the structure and contents of which are made up of oppression, fate and death. These three factors, and women's position 
in the confrontation with them, in casu Hallgerd, turns the drama of the saga into a continuous process of contention between two opposing forces, internality and externality, the freedom of the individual consciousness and the objective, external condition which would prevent her/him from achieving freedom and yet at the same time causes the drive towards freedom to be initiated. In concrete terms, individual freedom in the saga may be defined as the ability to act in order to change one's circumstances to the better; the women in the saga engage in action in an ambiguous fashion since they on the one hand act partly in opposition to the men and on the other hand emulate the actions of the men. This sort of ambiguous action highlights the power both men and women are up against, familial and social conditions that effectively constrain their actions and their pursuit of freedom. To a large extent, limitations, restrictions and constraints are not only external but internalized. The internalized constraints are visible in the form of fate and honor, concepts which, ironically and paradoxically, cause freedom to be pursued relentlessly while at the same time posing limits to that pursuit.

In her book The Ethics of Ambiguity Simone de Beauvoir points to a central paradox of our existence, commenting that man, meaning of course mankind, "escapes from his natural condition without, however, freeing himself from it"[2]. The author continues:

$\mathrm{He}$ is still a part of this world of which he is a consciousness. He asserts himself as pure internality against which no external power can take hold, and he also experiences himself as crushed by the dark weight of other things. At every moment he can grasp the non-temporal truth of his existence. But between the past which no longer is and the future which is not yet, this moment when he exists is nothing. This privilege, which he alone possesses, of being a sovereign and unique subject amidst a universe of objects, is what he shares with all his fellow-men. [2]

In the process of asserting their individuality and their individual freedom in the face of the objective condition a condition which emerges in the saga as fate and as the never-ending spiral of the family feud - women and men experience failure, and, as de Beauvoir comments, "without failure, no ethics' [2, p. 10]. Explaining this comment de Beauvoir notes that a being cannot be an exact coincidence with himself, because if he existed in a state of perfect plenitude then "the notion of having-to-be would have no meaning" [2, p. 10]. An ethical law cannot be a natural law, for it would degenerate into an abstract, rather than being a concrete coming into being in a continuous process of action. De Beauvoir states that "there can be a having-to-be only for a being who, according to the existentialist definition, questions himself in his being, a being who is at a distance from himself and who has to be his being" [2, p.11]. The women of Njal's Saga, in particular Hallgerd but also Bergthora and the Queen Gunnhild and others, are searching for an authentic being; citing Jean-Paul Sartre, de Beauvoir argues that realizing an authentic being means making oneself "a lack of being in order that there might be being" as the philosopher puts it in Being and Nothingness [3]. Passion is not imposed upon mankind from without. Women and men choose it. This places the concrete passion of the women characters in the saga in a unique perspective. Njal's son Skarphedin comments that "We're not made like women, that we become furious over everything" $[1$, p. 75$)$ in response to his mother Bergthora's statement that her sons have been given the gift of being called 'Dung-beardlings' and her husband Njal the gift of being called 'Old Beardless'. Skarphedin's comment is shown to be illogical by Bergthora who counters his statement by saying that Gunnar became furious on behalf of her sons. Fury is common to women and men in the saga. It is the emotion that drives the continuous, concrete quest for freedom. Fury is the manifestation of tension and failure. De Beauvoir comments on mankind's existence:

His being is lack of being, but this lack has a way of being which precisely existence is. In Hegelian terms it might be said that we have here a negation of the negation by which the positive is re-established. Man makes himself a lack, but he can deny the lack as lack and affirm himself as a positive existence. He then assumes the failure. And the condemned action, insofar as it is an effort to be, finds its validity insofar as it is a manifestation of existence. [2, p. 13]

The author further notes that "man must not attempt to dispel the ambiguity of his being but, on the contrary, accept the task of realizing it" [2, p.13]. Accepting this task means carrying out the ethics of ambiguity. This ambiguity may be conceived as recognition of the paradox of existence which is to be found on multiple levels. Being is a lack of being in the sense that being is becoming, i.e., being is constituted as a continuous striving to be; further, ambiguity exists as individual freedom of action constrained by yet continuously spurred on by the familial and the social environment, the so-called objective condition. - I believe the women Hallgerd and Bergthora accept the task of realizing these ambiguities by refusing to succumb to the objective condition perpetrated by the spiral of the family feud and by the inherent faith in fate that is most prominent in men, particularly Gunnar. The violent, furious response of Hallgerd in particular to the feuds instigated by the men, her response to the slaps in the face by three successive husbands, parodies to a great extent the larger plots of the men; the sub-plot designed by Hallgerd becomes a travesty of the feud. It is fed by anger, frustration and, indeed, by fury. Writing about Louis Ferdinand de Céline's novel Journey to the End of the Night [4] in her book The Powers of Horror [5] Julia Kristeva comments that in the novel we are presented with "a wild, obscene, and threatening femininity" [5, p. 167). Commenting on the woman character Gioconda in Céline's Guignol's Band, Kristeva states that the degraded power of 
Gioconda, a woman who trades sex, is changed into a "crafty reckoning" in women who are socialized as wives and mothers; here "hysterical spells turn to murderous plots, extreme masochistic poverty becomes a commercial triumph. While hysterical woman is merely a carnival puppet under a law she perversely attempts to get around, the paranoid woman becomes successful by making of herself the expression of a murderous sociality" [5, p. 168]. The women of Céline's novels, says Kristeva, exemplify "an otherness that cannot be sublimated - the sexual and the repressed, the marginal and the social. " - Further, "the intellectual woman does not escape being grotesque either", as she is "fated to prove the absurdity of reason (a masculine element) when it is sheltered in a body that is feminine to boot." [5, p.169] The marginal otherness that cannot be sublimated constitutes the truly carnivalesque. The women of the saga, especially Hallgerd, turn 'poverty' into a 'commercial triumph' by replenishing the household with butter and cheese in a year of near-famine. Hallgerd also exemplifies an 'otherness that cannot be sublimated' as she persist in asserting herself vis a vis a succession of husbands and as she consistently searches for reciprocated love and personal recognition for what and who she is.

Applied in unison, de Beauvoir's existentialist philosophy of ethics and Kristeva's psychoanalysis of the non-sublimated otherness of woman throw considerable light on the dynamics of the subjective and the objective, internality and externality, and the dynamics of gender relations in Njal's Saga. I now proceed to examine pertinent passages in the saga where I will try to highlight the manner in which the women, particularly Hallgerd and Bergthora, actively pursue freedom. I will also highlight the ironic undermining of gender exemplified by $\mathrm{Njal}$ himself.

\section{Gender and the Law}

Hair as an emblematic symbol of gender is a complex and paradoxical sign even from the beginning of the saga. Hallgerd is in possession of an abundance of rich hair flowing down to her waist. Njal is called Old Beardless, initially by her and then by other characters, e.g. Flosi who says about Njal that "there are many who can't tell by looking at him whether he's a man or a woman." [1, p.210]. A paradox emerges here, for is hair meant to be attached to womanhood, femininity, or detached from it? Njal's lack of facial hair indicates - within the field of public discourse - femininity, softness, and a tendency to engage in dialogue and arbitration leading to settlements rather than perpetrating the family feuds and the cycle of blood vengeance. The application of reason in the community is judged by a number of characters to be a weakness characteristic of women. Yet as we very well know the women of the saga are powerful, independent and in possession of a singularly excessive sexuality that challenges men. The women also possess an acute intelligence that in some cases, e.g. in the case of Queen Gunnhild, makes them capable of prophecy, an ability that Njal also possesses in full measure. Flosi's comment on the hybrid or fluid nature of Njal's gender follows his discovery of a silk robe placed on top of the pile of money given by Njal to ensure a settlement. Flosi interprets the robe as yet another feminine attribute, making a mockery of Njal's character; the silk robe becomes the instrument of rejection of the settlement, and the attack on Njal's house and the burning of Njal, Bergthora and their sons follow close upon Flosi's rejection.

The saga pits determinacy against indeterminacy when it comes to the issue of gender. Femininity is wrongly associated with weakness; feminine intelligence is mocked when it appears in Njal whose reason prompts him to set up a Fifth Court on Iceland in order to strengthen the Law. Public discourse describes him as effeminate in his proclivity towards reason and arbitration and the rule of law. The honorable thing to do is at all times to seek fame and honor, lof, by rightful vengeance and retribution. The public discourse exhibits a state of utter confusion when it comes to determining which qualities are manly, which are womanly, and which are legal and ethical. The rhetorical mixture and confusion of right and wrong and the stubborn adherence to the pursuit of fame and honor precipitates the action of the saga, making it follow a determined course construed by the participants as "fate". However, fate is not an objective condition imposed upon the women and men of the saga. They generate fate themselves by engaging in a false, i.e. abstract sublimation in the Hegelian sense of Aufhebung. A synthetic sublimation constitutes an inhuman objectivity. The existentialist view, in de Beauvoir's phrase, offers a very different understanding of the relationship between the subjective and the objective spheres; as the author puts it, "An ethics of ambiguity will be one which will refuse to deny a priori that separate existents can, at the same time, be bound to each other, that their individual freedoms can forge laws valid for all" [2, $p$. 18]. Njal's efforts concerning the Law and the setting up of the Fifth Court are manifestations of the subjective will and the objective condition working together in a field of free and mutual interdependence where nothing is fixed, absolute or substantive. Depriving Fate of its substance and creating a flexible Law is Njal's purposeful work. This work is preconditioned upon the hybrid or fluid nature of his gender which emerges as indeterminate in a culture where the struggle surfacing in society as the "feud" is the outcome of an absurd insistence on determinacy. This makes the character of Njal particularly modern as gender is seen to be something negotiable. This negotiable status of gender, it's very indeterminacy, furthermore, anticipates and indeed represents a Christian gentleness of character that is combined with reason and introspection. These qualities are seen to be preconditions for the establishment of the Rule of Law on Iceland. Njal views the Law and the 
Fifth Court as indispensable for the abolition of the feuds and for the creation of a new society.

Besides Njal himself, the women are the primary actors in the revolt against determinacy. Hallgerd's excess of hair signifies an abundance of sexuality that crosses the boundaries between the feminine and the masculine. "Old Beardless", Njal, becomes an extension of feminine power; in him, the power of the feminine par excellence shows itself as a diversity of character that includes reason, clear thinking, prophecy and law. These qualities emanate from the women, Queen Gunnhild, Hallgerd and Bergthora whose deeper purpose is to construct their being in freedom as Simone de Beauvoir describes it.

Queen Gunnhild starts a sexual relationship with Hrut, a man much younger than her. As he prepares to leave for Iceland, Gunnhild asks him whether he has a woman out there, to which he replies 'no'. She reacts by casting a spell:

If I have as much power over you as I think I have, then I cast this spell: you will not have sexual pleasure with the woman you plan to marry in Iceland, though you'll be able to have your will with other women. Neither of us comes out of this well, because you did not tell me the truth. [1, p.13]

The spell works. Hrut marries Unn who divorces him because of impotence. Queen Gunnhild's requirement for the truth is not the reaction of a jealous woman; it is a demand for truthfulness among equal partners. In this first portrayal of a male-female relationship the saga sets the stage for a number of relationships, the most significant ones being Hallgerd's three marriages, where the woman partner's requirement for equality and what follows from it, i.e. lack of any kind of forcefulness and possessiveness. Hallgerd is described by a number of male characters as strong-minded, lavish and as having a thief's eyes; yet her father Hoskuld more or less forces her to marry Thorvald, a proposal she is against. The marriage proceeds without her being consulted, and she reacts by demanding to have whatever the neighbors had and squanders everything, creating a shortage of flour and fish for which she criticizes Thorvald who in turn slaps her in the face. Thjostolf, a slave, volunteers to avenge the slap and kills Thorvald, an action undertaken in order to free Hallgerd to marry a second time. Hallgerd's squandering of foodstuffs is an example of what Kristeva describes as the lavish behavior of uncontained women acting forcefully in the one sphere where they hold sway, the household. Hallgerd compensates for her state of un-freedom by exceeding the material boundaries that guard and guarantee the survival of the family. The slap in the face is enough to release action against the perpetrator; it is significant, however, that the man, Thjostolf, volunteers to avenge the physical abuse. A subtly ironic pattern emerges here. Freedom of being, here the freedom of one of the most important women in the saga, is pursued - or has to be pursued negatively as a response to un-freedom. This dialectical scheme is not as simple as the male quest for vengeance, fame and honor in the feud which always occurs in direct response to a perceived injustice, real or imagined, factual or construed. Indeed, the male quest for blood-vengeance is often construed in an irrational manner as we see it in Flosi's rejection of the settlement with Njal. By contrast, the feminine pursuit of freedom is undertaken upon the background of a lack that has to be filled or repaired continuously in an effort to sustain the ongoing construction of being in freedom. Thus the freedomun-freedom dialectic, as it manifests itself in Hallgerd, is the unfolding of being as becoming, which de Beauvoir calls "a tending towards this being" [2, p. 13]. Hallgerd tends to become, and this movement is reinforced by the repetition of the primary slap. Her second husband Glum, whom she agrees to marry, slaps her when they get into an argument involving sheep and Thjostolf, who is a slave and yet a close friend of Hallgerd's. Glum is killed by Thjostolf. The repetitive pattern continues when Gunnar slaps Hallgerd in an argument that once again has to do with food, the shortage of food and stolen food. Hallgerd steals food from a neighbor even though $\mathrm{Njal}$ has given Gunnar plenty of food to hold out during the winter. The emphasis on material deprivation and material abundance may be analyzed as a mirror reflecting women's self-empowerment through distorting it and through relegating it to a lower sphere, the material sphere where empowerment generates excessive, even grotesque behavior. The manifest display of a woman's power and her design to gain power intentionally distorts the "tending towards this being", in de Beauvoir's phrase. It also challenges the men, both Gunnar and Njal, whom Hallgerd calls soft. Nevertheless, the overt display of power merely constitutes the surface of the deeper desire: the will to construct being as becoming. As we know, the third slap is fatal since it causes Hallgerd's refusal to give Gunnar two locks of her hair.

\section{Fate and Prophecy}

Prophecy assumes an ambiguous meaning in the saga as it posits an inevitable outcome while at the same time positing a potential freedom by including a potential escape from fate and inevitability on condition the individual chooses freedom by embracing a reasonable conduct. Choosing freedom when confronted with fate as a concrete phenomenon that is not the manifestation of an objective condition but rather the projection of a secret, ill understood, subconscious desire points to a central concern in Njal's Saga: it is concerned with an ironic disclosure of even the strongest characters' immanent tendency to remain unconscious of the forces that govern them from within, or rather, their seeming lack of conscious realization and awareness of their innate ability to turn 
things around. Their lack of awareness is only an apparent lack; lurking beneath the surface of their often ill-considered actions, actions that indeed propel them towards death, we find a deeply ironic and self-ironic rhetorical substratum, often in the form of the famous grin, a non-verbal gesture that speaks volumes in spite of its being an extra-linguistic language, a paradoxical miming or acting that places the actor in a dumb show. A significant example of this dumb show occurs in the middle of the killing of slaves perpetrated by Hallgerd and Bergthora as they engage in a cycle of vengeful actions against one another:

Hallgerd was told of Kol's slaying and of Atli's comments. She said she would pay him back. She sent a man to the Thing to tell Gunnar of Kol's slaying. He had little to say about it and sent a man to Njal to let him know. Njal said nothing.

Skarphedin spoke: 'Slaves are much more active than they used to be: then they just got into brawls, and that seemed harmless enough, but now they're out to kill each other.'

He grinned. [1, p.63]

The passage reveals that both Gunnar and Njal are taciturn in the face of the growing spiral of violence occurring within their own households. Their taciturn reaction would imply giving in to fate, and perhaps at the same time leaving affairs at the household in the hands of the women. Not reacting jeopardizes relations between the families and in the community overall and signifies a passivity in the face of fate and death, a succumbing to the objective condition that they are orchestrating themselves. The active orchestration of a fateful outcome and of death is amply present in the prophecies issued by $\mathrm{Njal}$ and Gunnar both. The prophecy doubles back upon the prophet, ironically so since the knowledge of events to come and the awareness of the shape of the future would be conducive to possible interference and intervention, an intervention that never occurs. Skarphedin's grin adds more meaning to the whole scene, as the grin implies his awareness of the dangers involved in domestic affairs that are not only domestic but constantly spilling over into the entire community. Moreover, the grin betrays a double or multiple irony as it becomes a non-spoken but yet very outspoken sign of Skarphedin's knowledge of the close relationship between domestic and public on Iceland. He knows what is going on and, to a great extent, also knows what can and will happen. Further, the grin is self-ironic because it signifies his unwillingness to act on his insight. This unwillingness shows an acquiescence in the face of fate and death that he and most of the other characters construe as a necessary succumbing to things as they must be. Here yet another irony emerges, for construing something as necessary is of course an absurd paradox and points to the very nature of the problem: that which is necessary does not come from without but from within. It is internality projecting itself onto the external world while being more than dimly aware of the mental mechanism governing this projection. Once more, the awareness of how things work, within the mind and without in society entails inaction instead of action. The grin is amplified.

In response to Gunnar's request that he reveal the future, Njal responds with a prophecy: "Never kill more than once within the same bloodline, and never break any settlement which good men make between you and others, least of all if you have broken my first warning" [1, p.94]. Gunnar proceeds to kill twice within the same bloodline and is sentenced to three years in exile as an outlaw. He accepts the settlement but in the last minute before leaving he resolves to stay on Iceland. He makes his decision because of the loveliness of the hillside: "Lovely is the hillside never has it seemed so lovely to me as now, with its pale fields and mown meadows, and I will ride back home and not leave." Gunnar's attachment to home is an aesthetic one, almost akin to a Wordsworthian fascination with "the splendour in the grass", and "the glory in the flower" [6]. The power of nature and beauty overwhelms him and evokes our understanding and sympathy. Beauty is a powerful agent but comes too late to save him. In Gunnar, a pre-Romantic love that might have been fulfilled if he had requited Hallgerd's love for him is aestheticized as it becomes a love for nature and home. The woman is forgotten in the process. Postponing the right action that would save him from his "fate" and not heeding Njal's prophecy, he falls prey to the wolves that appear in an earlier dream at night. Thus Gunnar fulfills his own prophecy: "Death will come to me no matter where I am," said Gunnar, "if that is my fate." [1, p.114]

$\mathrm{Njal}$ the prophet knows more clearly than the others what will follow from the cycle of slayings. When asked by his son Skarphedin what will follow, Njal replies: "My death and that of my wife and all my sons." [1, p.188] When Flosi offers him free exit before the burning of the house, Njal replies, "I will not leave for I am an old man and hardly fit to avenge my sons, and I do not want to live in shame." Bergthora also declines the offer of exit, stating that she promised Njal that one fate should await them both.

A final ambiguity emerges here. Njal's acceptance of death may be read in two ways: As a fulfillment of fate and as a gesture of freedom. Simone de Beauvoir writes about violence, sacrifice and death that even if the individual decides that "in order to justify his life he must consent to limiting its course, even if he accepts dying, there is a wrench at the heart of this acceptance, for freedom demands both that it recover itself as an absolute and that it prolong its movement indefinitely" [2, p. 107]. Here is the ambiguity. Death puts an end to the "indefinite movement"; the individual can "transcend death toward a future fulfillment, but he will not be present in that future" $[2$, p.107] Njal's statement that he does not want to live in shame is both a fulfillment of death and a transcendence of death, a freedom from it. 


\section{Conclusions}

The character Njal and the women of Njal's Saga struggle significantly, even heroically, to bring about a new society on Iceland. During the struggle they come to exhibit what Simone de Beauvoir conceptualizes as ambiguous freedom and ambiguous being. They also manifest, to a lesser extent perhaps, what Julia Kristeva refers to as an otherness that cannot be sublimated. Fate and honor, in their internalized form, are ironically pitted against the pursuit of love and freedom exemplified most powerfully in the woman character Hallgerd and in Njal. The burning of Njal and his acceptance of death epitomize the strange paradox of freedom and fate in the saga.

\section{REFERENCES}

[1] Njal's Saga (translated by Cook R. ) London: Penguin Books; 1997

[2] De Beauvoir S. The Ethics of Ambiguity (translated by Frechtman B). New York: Philosophical Library; 1948

[3] Sartre, JP. Being and Nothingness (translated by Barnes HE). New York: Philosophical Library; 1956

[4] Céline, LF. Journey to the End of the Night. (translated by Marks JHP) Boston: Little, Brown; 1934

[5] Kristeva J. Powers of Horror: An Essay on Abjection (translated by Roudiez LS) New York: Columbia University Press; 1982

[6] Wordsworth W. "Ode. Intimations of Immortality". In: Quiller-Couch A, ed. Oxford: The Oxford Book of English Verse; 1919 